\title{
PARTISIPASI GUCIALIT ORGANISASI WISATA ALAM (GOWA) DALAM PENGEMBANGAN AGROWISATA KEBUN TEH KERTOWONO DI KECAMATAN GUCIALIT KABUPATEN LUMAJANG
}

\author{
Nadlirotun Nisa' ${ }^{1}$, Joko Widodo ${ }^{1}$, Sutrisno Djaja ${ }^{1}$ \\ ${ }^{1}$ Program Studi Pendidikan Ekonomi, Fakultas Keguruan dan Ilmu Pendidikan, Universitas Jember \\ E-mail: nadlirotunnisa@gmail.com
}

\begin{abstract}
Abstrak
Pariwisata merupakan sebuah industri jasa yang digunakan sebagai salah satu pendorong perekonomian masyarakat sekitar. Pola pengelolaan dan pengembangan wisata perlu dilakukan dengan mengikutsertakan masyarakat setempat dalam kegiatan yang menunjang usaha agrowisata. GOWA (Gucialit Organisasi Wisata Alam) merupakan organisasi masyarakat di Kecamatan Gucialit yang bergerak dibidang lingkungan dan sosial. GOWA bekerjasama dengan PTPN XII untuk mengembangkan agrowisata kebun teh Kertowono. Adanya GOWA dalam mengembangan wisata kebun teh dapat menjaga keberlanjutan usaha obyek wisata. Kesediaan GOWA dan melibatkan masyarakat dalam mengembangkan obyek wisata merupakan salah satu bentuk partisipasi masyarakat. Penelitian ini bertujuan untuk mengetahui bentuk partisipasi yang dilakukan organisasi masyarakat melalui Gucialit Organisasi Wisata Alam (GOWA) dalam pengembangan agrowisata kebun teh. Penelitian ini termasuk penelitian kualitatif. Penentuan daerah penelitian dan informan menggunakan metode purposive. Adapun untuk memperoleh data peneliti menggunakan metode wawancara mendalam sebagai metode utama, serta observasi dan dokumen sebagai data pelengkap. Data yang terkumpul dianalisis menggunakan analisis deksriptif kualitatif. Hasil penelitian menunjukkan bahwa bahwa partisipasi GOWA dalam pengembangan agrowisata kebun teh Kertowono terdiri dari 3 bentuk partisipasi yaitu partisipasi dalam pengambilan keputusan, partisipasi dalam pelaksanaan dan partisipasi dalam pengambilan manfaat. Partisipasi dalam pengambilan keputusan GOWA dalam pengembangan agrowisata yaitu memberikan ide karnaval tahunan untuk melestarikan kesenian dan juga sebagai ajang promosi wisata kebun teh Kertowono serta menghadiri rapat dengan masyarakat sekitar Kecamatan Gucialit. Partisipasi dalam pelaksanaan yaitu melakukan promosi melalui sosial media dan melaksanakan konservasi lingkungan. Partisipasi GOWA dalam pengambilan manfaat yaitu memberikan manfaat ekonomi dan lingkungan. Manfaat ekonomi yaitu masyarakat meningkat dengan adanya wisata kebun teh Kertowono dengan bekerja sebagai pemandu, tukang parkir maupun berjualan di sekitar wisata dan memberikan manfaat lingkungan yaitu adanya pemandu wisata yang disediakan oleh GOWA juga membantu menjaga kelestarian lingkungan dengan melakukan patrol untuk menghindari adanya perusakan hutan.
\end{abstract}

Kata Kunci: partisipasi, agrowisata, kebun teh, organisasi wisata

\section{PENDAHULUAN}

Pariwisata merupakan sebuah industri jasa yang digunakan sebagai salah satu pendorong perekonomian dunia dan juga merupakan industri dengan pertumbuhan yang cepat di dunia. Baik itu berupa peristiwa ataupun situasi yang terjadi dalam berbagai bidang aspek kehidupan dan lingkungannya. Pariwisata sangat berhubungan dengan aspek ekonomi, namun tidak hanya langsung berkaitan dengan kegiatan pariwisata seperti usaha perhotelan, restoran dan penyelenggara paket wisata. Banyak kegiatan ekonomi lainnya yang berhubungan erat dengan pariwisata, seperti transportasi, telekomunikasi, dan bisnis eceran. Pengembangan pariwisata haruslah memperhatikan terjaganya mutu lingkungan, sebab dalam industri pariwisata, lingkungan itulah yang sebenarnya dijual.

Pola pengelolaan dan pengembangan agrowisata perlu dilakukan dengan mengikutsertakan masyarakat setempat dalam kegiatan yang menunjang usaha agrowisata. Keterlibatan masyarakat di dalam pengembangan agrowisata diharapkan dapat dikembangkan pula interaksi posiitf dalam berbagai kegiatan untuk menjaga eksistensi obyek wisata. Sesuai model pengembangan agrowisata, masyarakat lokal adalah komponen penting yang perlu diikutsertakan dalam setiap aspek pengembangan. Kesediaan masyarakat dalam mengembangkan obyek wisata merupakan salah satu bentuk partisipasi masyarakat.

Data Kantor Pariwisata Kebupaten Lumajang tahun 2016 menunjukkan bahwa terdapat obyek agrowisata yang berpotensi sebagai agrowisata di Kabupaten Lumajang, yaitu Kebun Teh Kertowono, Kecamatan Gucialit. Kawasan ini berada di bawah naungan PT. Perkebunan Nasional XII ( PTPN XII). Daya tarik agrowisata yang terdapat di Kebun Teh Kertowono adalah agowisata kebun teh, air terjun semingkir juga terdapat daya tarik wisata seri Reog Campursari dan Kesenian Ujung. Kebun Namun, potensi pariwisata yang besar ini masih belum 
sepenuhnya dikembangkan dan dimanfaatkan secara optimal. Minimnya pemahaman masyarakat sekitar terhadap potensi alam di wilayahnya membuat Kebun Teh Kertowono tidak begitu dikenal wisatawan domestik maupun mancanegara.

Pada tahun 2010 ada tujuh pemuda yang menyukai petualangan, beberapa diantaranya suka berkunjung ke tempat-tempat wisata dan beberapa sebagai pendaki gunung. Mereka mempunyai inisiatif membentuk organisasi Pecinta Wisata Gucialit (PWG) untuk mengembangkan potensi wisata yang ada di desa tersebut dengan menggali potensi-potensi wisata. Pada tahun 2013 ada beberapa orang tua yang bergabung sebagai pembina, sehingga PWG dikokohkan kembali menjadi Gucialit Organisasi Wisata dan dibentuk struktur organisasi. GOWA (Gucialit Organisasi Wisata Alam) melakukan beberapa kegiatan yang dinilai dapat membantu masyarakat di Kecamatan Gucialit dalam mempromosikan obyek wisata. Organisasi tersebut dibentuk karena penggeraknya lebih memahami mangsa pasar yang harus dilalui untuk mempromosikan potensi agrowisata tersebut.

Hal ini merupakan salah satu upaya untuk memberdayakan potensi wisata dan masyarakat sekitar kebun teh, karena pariwisata dapat memberikan dampak positif dalam membuka kesempatan kerja dalam mendorong partisipasi organisasi dalam membantu masyarakat sekitar. Kebun Teh Kertowono memiliki potensi besar dalam pengembangan agrowisata sehingga mendorong organisasi GOWA agar terus berupaya dalam mempromosikan agrowisata. Adanya kesadaran anggota organisasi dalam membantu mempromosikan agrowisata, diharapkan dapat dikembangkan pula interaksi positif dalam bentuk rasa ikut memiliki untuk menjaga keberlanjutan usaha obyek wisata.

Saat ini permasalahannya perlu adanya promosi terhadap obyek wisata kebun teh Kertowono agar benarbenar dapat dijadikan sebagai obyek wisata alam sebagai daya tarik wisata Kabupaten Lumajang baik untuk wisatawan domestic maupun mancanegara. Hal ini dikarenakan kurangnya kesadaran masyarakat terutama generasi muda terhadap obyek wisata alam di daerahnya sendiri, karena jika promosi terus menerus dilakukan akan berdampak pada perekonomian masyarakat sekitar Kecamatan Gucialit. Adanya GOWA akan berdampak pada meningkatnya jumlah pengunjung kebun teh Kertowono meskipun tidak secara signifikan, tetapi sejauh ini semakin lama semakin meningkat. Hal ini membawa pengaruh juga bagi Dinas Pariwisata Kabupaten Lumajang dalam hal promosi obyek wisata di Kabupaten Lumajang.

Partisipasi komunitas GOWA dalam mengembangkan destinasi wisata yang ada di Kecamatan Gucialit yaitu mewujudkan Gucialit yang lestari dan asri sehingga bisa dimanfaatkan potensi ekonominya oleh masyrakat Gucialit. Kenyataan masyarakat tentang pentingnya kelestarian lingkungan masih rendah. GOWA berusaha untuk memberikan kesadaran kepada masyarakat sekaligus mengajak masyarakat agar berpartisipasi aktif melalui kegiatan pelestarian lingkugan. Kegiatan pelestarian lingkungan yang dilakukan adalah lomba mewarnai gambar keindahan alam Gucialir untuk siswa PAUD dan TK, bersih sampah dan penghijauan. GOWA juga membantu pihak pemerintah mensosialisasikan kebijakan undang-undang pelestarian lingkungan. Adanya organisasi GOWA dan kegiatan-kegiatannya memberikan dampak yaitu berkurangnya penebangan liar di Kecamatan Gucialit, rehabilitasi dan konservasi daan wisata alam Gucialit menjadi lebih dikenal. Wisata alam yang dikenalkan oleh GOWA di Kecamatan Gucialit yaitu kebun teh Kertowono. Partisipasi GOWA dalam pengembangan wisata kebun teh kertowono yaitu mempromosikan lewat media sosial, membuat merchandise karya GOWA sebagai oleh-oleh wisatawan sebagai media promosinya juga dan menjaga kelestaria tempat wisata.

Partisipasi adalah turut sertanya seseorang baik secara mental maupun emosional untuk memberikan sumbangsih pada proses pembuatan keputusan terutama mengenai persoalan-pesoalan dimana keterlibatan pribadi yang bersangkutan melaksanakan kewajibannya melakukan hal tersebut. (Winardi, 2000:63). Partisipasi adalah keikutsertaan anggota organisasi dalam masyarakat mengenai proses pengidentifikasian masalah dan potensi yang ada di masyarakat, pemilihan dan pengambilan keputusan tentang alternatif solusi untuk menangani masalah, pelaksanaan upaya mengatasi masalah, dan keterlibatan masyarakat dalam proses mengevaluasi perubahan yang terjadi (Isbandi, 2007:27). Partisipasi merupakan suatu bentuk keterlibatan dan keikutsertaan secara aktif dan sukarela, baik karena alasan intrinsik maupun ektrinsik dalam keseluruhan proses kegiatan yang bersangkutan. Partisipasi masyarakat sebagai anggota organisasi dibagi dalam empat macam kegiatan dalam proses pengembangan dan pembangunan, yaitu partisipasi dalam pengambilan keputusan, partisipasi dalam pelaksanaan dan partisipasi dalam pengambilan manfaat (Mardikanto, 2013:82).

Partisipasi dalam pengambilan keputusan artinya bentuk perbuatan berpikir dan hasil dari suatu perbuatan. Partisipasi ini terutama berkaitan dengan penentuan alternatif dengan masyarakat yang berkaitan dengan gagasan atau ide yang menyangkut kepentingan bersama. Dalam partisipasi ini masyarakat menuntut untuk ikut menentukan arah dan orientasi pembangunan. Wujud dari partisipasi ini antara lain seperti kehadiran rapat, diskusi, sumbangan pemikiran, tanggapan atau penolakan terhadap program yang ditawarkan (Desmita 2008: 198). Partisipasi dalam pelaksanaan merupakan keterlibatan masyarakat untuk ikut serta dalam mendukung terlaksananya pembangunan baik kontribusi dalam memberikan tenaga, bahan baku maupun finansial dengan memberikan sumbangan pembiayaan bagi terselengaranya pembangunan. Partisipasi dalam pelaksanaan merupakan kelanjutan dalam rencana yang telah digagas sebelumnya baik yang berkaitan dengan perencanaan, 
pelaksanaan maupun tujuan. Partisipasi dalam pelaksanaan meliputi menggerakkan sumber daya, kegiatan administrasi, koordinasi dan penjabaran program. (Kaselaran dkk, 2015: 8). Partisipasi dalam pengambilan mandaat merupakan bentuk keterlibatan masyarakat untuk turut menikmati dan memanfaatkan hasil-hasil pembangunan yang sudah terlaksana. Bukan hanya menikmati, tetapi masyarakat juga diharapkan dapat berpartisipasi dalam menjaga, merawat, dan memelihara hasil-hasil pembangunan yang telah dilakukan. Pemanfaatan hasil pembangunan tersebut diharapkan dapat mengungkit daya kreatifitas masyarakat, kegiatan ekonomi dan mobilitas sosial, peningkatan kesejahteraan masyarakat, yang pada akhirnya dapat mencapai pembangunan yang lebih baik lagi (Sagitta, 2016: 313).

Peneliti tertarik meneliti GOWA karena organisasi tersebut masih mempertahankan eksistensinya selama 17 tahun. GOWA berdiri atas kesadaran pemuda-pemuda Gucialit terhadap kelestarian lingkungannya dan tanpa bantuan dana dari luar. GOWA berdiri tahun 2012 dan bergerak di bidang pariwisata, lingkungan dan pengembangan sumber daya manusisa. GOWA berhasil mengeksplor potensi yang wisata salah satunya yaitu kebun teh kertowono yang bekerjasama dengan PTPN XII Kertowono. Penelitian ini bertujuan untuk mengetahui bentuk partisipasi GOWA dalam pengembangan agrowisata kebun teh Kertowono.

\section{METODE PENELITIAN}

Penelitian ini termasuk penelitian kualitatif. Penentuan daerah penelitian dan informan menggunakan metode purposive. Informan yang digunakan dalam penelitian terdiri dari informan inti dan 3 informan tambahan. Informan utama yang diambil yaitu pendiri Gucialit Organisasi Wisata Alam (GOWA) dan anggota GOWA. Informan tambahan yang digunakan dalam penelitian yaitu masyarakat sekitar kebun teh, staff dinas pariwisata dan pengunjung obyek wisata kebun teh Kertowono. Adapun untuk memperoleh data peneliti menggunakan metode wawancara mendalam sebagai metode utama, serta observasi dan dokumen sebagai data pelengkap. Data yang dikumpulkan dianalisis mengunankan analisis deskriptif kualitiatif. Analisa data penelitian meliputi reduksi data, penyajian data, dan penarikan kesimpulan (verifikasi).

\section{HASIL DAN PEMBAHASAN \\ Hasil Penelitian}

Partisipasi GOWA dalam pengembangan agrowisata kebun teh Kertowono dilihat dari bentuk kegiatan partisipasinya yaitu partisipasi dalam pengambilan keputusan, partisipasi dalam pelaksanaan dan partisipasi dalam pengambilan manfaat. Berikut penjelasan masing-masing kegiatan partisipasi yang dilakukan GOWA dalam pengembangan agrowisata kebun teh Kertowono yaitu:

1. Partisipasi dalam pengambilan keputusan

Kegiatan yang dilakukan oleh GOWA dalam pengembangan agrowisata kebun teh Kertowono tidak terlepas dari keterlibatan masyarakat sekitar juga. Pengembangan agrowisata kebun teh Kertowono bekerjasama dengan PTPN XII. Partisipasi dari GOWA (Gucialit Organisasi Wisata Alam) sendiri berperan penting dalam pengembangan obyek wisata. Ide-ide kreatif yang muncul dari pemikiran pemuda seringkali dapat membuka cara berpikir masyarakat maupun pengelola PTPN XII untuk lebih maju dalam mengenalkan potensi wisata pada masyarakat luas dan wisatawan. Seperti yang disampaikan Jefri sebagai berikut :

“.....sampai saat ini kami dr GOWA masih diikutsertakan dalam musyawarah dengan pihak PTPN XII dan Dinas Pariwisata, karna terkadang ide-ide dari kami justru yang digunakan karna mungkin dari pemikiran kami yang lebih tau media sosial.." (J,22th)

Berdasarkan hasil wawancara, GOWA menyumbangkan banyak ide dan pendapat baik untuk menyusun beberapa program yang masih direncanakan maupun untuk memperlancar pelaksanaan program, dan mewujudkannya dengan memberikan pengalaman saat berwisata di obyek wisata lain yang sudah dikelola maupun mengembangkan kegiatan yang sudah ada sebelum adanya GOWA. Partisipasi GOWA dalam pengambilan keputusan yaitu mengemukakan pendapatnya melalui rapat kemudian meminta masukan, saran dan kritik. Salah satu ide yang dikemukan yaitu karnaval tahunan. Karnaval tahunan ini merupakan salah satu ajang untuk melestarikan kesenian sekaligus ajang promosi wisata kebun teh Kertowono. Berdasarkan hasil wawancara dengan subyek penelitian yang terlibat langsung dalam kegiatan rapat mengenai pengembangan agrowisata kebun teh Kertowono.

"rapat rutin juga diadakan rapat bareng perwakilan masyarakat, tokoh masyarakat, ketua $R T / R W$ sekitar" (D,23th)

Pernyataan diatas menyatakan bahwa rapat rutin selalu dilakukan bersama perwakilan masyarakat, tokoh masyarakat dan ketua RT/RW. Rapat mengenai pengembangan agrowisata yang dibahas mengenai promosi agrowisata dan menjaga kelestarian wisata agrowisata. GOWA melibatkan masyarakat untuk menyebarkan agrowisata melalui sosial media. Kegiatan promosi dan menjaga kelestarian di lokasi wisata yang sudah terlaksana juga hasil keputusan bersama yang melibatkan masyarakat. Berikut hasil wawancara yang dilakukan dengan informan D: 
“....beberapa kegiatan yang terlaksana juga merupakan hasil keputusan dari rapat rutin semua anggota GOWA yang disetujui dan didukung pihak PTPN XII dan Dinas Pariwisata” (D,23th)

Partisipasi dalam pengambilan keputusan yang dilakukan oleh GOWA yaitu GOWA ikut terlibat dalam rapat untuk mengembangkan agrowisata kebun teh Kertowono. GOWA mengemukakan pendapat dan ide dalam rapat yang dihadiri oleh masyarakat, meminta saran kepada masyarakat dan kerjasama dengan masyarakat dalam mewujudkan idenya. Kegiatan yang akan dilakukan GOWA yaitu promosi wisata dan melakukan konservasi hutan.

2. Partisipasi dalam pelaksanaan

Partisipasi GOWA dalam pelaksanaan pengembangan agrowisata dilihat dari jumlah yang aktif berpartisipasi dan bentuk partisipasi. GOWA berjumlah orang 85 orang. Rata-rata yang masuk dalam GOWA berpartisipasi aktif semua. Bentuk partisipasi GOWA terhadap pengembangan agrowisata kebun teh yaitu mengadakan karnaval sebagai ajang promosi agrowisata kebun teh juga melestarikan kesenian yang dimiliki oleh masyarakat Gucialit.

“....setiap tahun selalu diadakan karnaval yang digagas oleh kami sebagai untuk melestarikan kesenian juga ajang promosi agrowisata kebun teh.” (J,22th)

GOWA juga melakukan kegiatan sosial berupa konservasi hutan wilayah sekitar kebun teh dengan melakukan patroli keliling hutan pada saat-saat tertentu untuk menjaga agar hutan sekitar kebun teh Kertowono tetap aman dan tidak disalahgunakan oleh oknum-oknum nakal. GOWA dalam implementasi pengembangan agrowisata kebun teh Kertowono yaitu melakukan promosi melalui media sosial. Berikut hasil wawancara dengan informan:

“...promosi dengan menggunakan media sosial dan menjalin hubungan dengan Dinas Pariwisata dan Budaya agar menyaranan pengunjung dari luar daerah Lumajang untuk menggunakan jasa GOWA.” $(J, 22 t h)$

Partisipasi GOWA dalam partisipasi implementasi atau pengelolaan wisata yaitu melakukan kegiatan sosial dengan tujuan menjaga kelestarian tempat wisata. GOWA terbagi dua divisi yaitu konservasi dan wisata. GOWA dalam divisi kepariwisataan, sebagai pemandu wisata bagi wisatawan yang mengunjungi kebun teh Kertowono maupun yang berkunjung ke air terjun di wilayah sekitar kebun teh Kertowono. Dengan adanya pemandu wisata dari GOWA diharapkan dapat meminimalisir kegiatan negatif yang mungkin dilakukan oleh wisatawan, seperti mencorat-coret beberapa fasilitas, buang air disembarang tempat atau berniat mencari tempat untuk dapat melakukan tindak asusila dan lain-lain. Beriku hasil wawancara dengan informan :

“...GOWA terbagi menjadi 2 divisi yaitu konservasi dan kepariwisataan. Saya jelaskan divisi konservasi adalah divisi yang bergerak di lingkungan ataupun misalnya ada kegiatan penanaman atau ikut menjadi polisi hutan. Divisi kepariwisataan yaitu sesuai dengan tempat kita saat ini lokasi wisata dengan menggali potensi wisata dan ikut mengembangkan SDM masyarakat Gucialit, serta menyiapkan kegiatan yang berkaitan dengan kepariwisataan." (J,22th)

Selain itu, partisipasi beberapa anggota GOWA yang tergabung dalam divisi konservasi juga berpengaruh terhadap pengembangan pariwisata. Sebagian anggota GOWA ikut dalam kegiatan penanaman atau ikut menjadi polisi hutan. Seperti halnya kepariwisataan, divisi konservasi juga melakukan kegiatan pengembangan pariwisata. Sesuai dengan namanya, kegiatan yang dilakukan tidak luput dari kegiatan pelestarian atau perlindungan. Kegiatan yang dilakukan GOWA adalah menjaga ekosistem hutan dengan melakukan patroli di hutan sekitar Gucialit untuk menghindari adanya oknum-oknum perburuan liar, penebangan liar dan perusakan hutan.

Berdasarkan hasil wawancara yang dilakukan peneliti, sejak awal terbentuknya GOWA murni adanya kesadaran pemuda Gucialit digagas sebagai pelopor kesadaran akan potensi pariwisata yang tersembunyi. Semakin berkembangnya pariwisata di daerah Gucialit membuat semakin meningkatnya ide-ide kreatif GOWA dalam membantu masyarakat. Tidak hanya membantu dalam meningkatkan jumlah pengunjung saja, namun GOWA menjadi salah satu bagian dari masyarakat yang sadar akan kegiatan sosial. Dalam hal ini GOWA melakukan beberapa kegiatan yang bersifat sosial, seperti halnya konservasi hutan di sekitar kebun teh kertowono dengan melakukan patroli untuk mengurangi dan memberantas oknum-oknum penebang hutan liar serta pemburu binatang liar.

Berikut hasil wawancara dengan informan:

“...saya jelaskan GOWA adalah organisasi pariwisata yang bergerak murni dalam kegiatan sosial,” $(D, 23 t h)$

Partisipasi dalam pelaksanaan yang dilakukan oleh GOWA untuk mengembangkan agrowisata kebun teh Kertowono yaitu mengadakan karnaval untuk melestarikan kesenian dan sebagai ajang promosi untuk menarik pengunjung untuk mengunjungi agrowisata kebun teh Kertowono. Selain itu, GOWA juga melakukan promosi menggunakan sosial media dan juga ikut melakukan konservasi hutan dengan patrol ke hutan-hutan.

3. Partisipasi dalam pengambilan manfaat 
GOWA memberikan manfaat kepada masyarakat sekitar. Adanya promosi yang dilakukan menjadikan agrowisata kebun teh Kertowono didatangi banyak pengunjung. GOWA menyediakan pemandu wisata, menyediakan areal parkir, dan warung makan. Semua yang dilakukan oleh GOWA melibatkan masyarakat. Secara tidak langsung, adanya kegiatan yang dilakukan oleh GOWA memberikan perekonomian bagi GOWA dan juga masyarakat. Berikut hasil wawancara dengan informan tambahan:

“...sesudah adanya GOWA lebih banyak orang yang berkunjung, ya arena disini saya juga membuka warung kopi, pendapatan saya jadi meningkat drastic karena banyak pengunjung yang datang untuk berwisata baik dari masyarakat lumajang aupun luar lumajang. Bahkan luar negri lho mbak." (S,35th)

Promosi yang dilakukan oleh GOWA melalui karnaval tahunan dan sosial media menyebabkan semakin banyak pengunjung yang berkunjung ke agrowisata kebun teh Kertowono. Masyarakat sekitar pun mendapatkan manfaat ekonomi, karena dilibatkan untuk menjadi pemandu wisata, penjaga parkir serta diberi kebebasan untuk berjualan di lokasi wisata kebun teh Kertowono. Pendapatan masyarakat meningkat dengan adanya wisata kebun teh Kertowono ini. Selain memberikan manfaat ekonomi kepada masyarakat, GOWA juga memberikan manfaat lingkungan. Adanya pemandu wisata yang disediakan oleh GOWA juga membantu menjaga kelestarian lingkungan dengan melakukan patrol untuk menghindari adanya perusakan hutan.

Perkembangan wisata kebun teh setelah adanya GOWA yaitu wisata kebun teh semakin menarik karena dipasang papan petunjuk untuk lokasi-lokasi spot foto menarik. GOWA juga telah membangun ikon wisata kebuh teh, gazebo di Puncak 74 dan spot foto perahu dibawah hamparan kebun teh. Kedai dingin yang dibangun GOWA menyediakan menu khas Gucialit seperti teh hitam. Selain itu, GOWA juga menjual berbagai merchandise untuk oleh-oleh khas wisata kebun teh. Karnaval yang digagas GOWA menjadi acara tahunan di Kecamatan Gucialit. Berbagai kegiatan yang dilakukan GOWA tersebut terbukti dapat menarik wisatawan untuk berkunjung di wisata kebun teh ini.

\section{Pembahasan}

Mardikanto (2013:82) menyatakan bahwa partisipasi merupakan suatu bentuk keterlibatan dan keikutsertaan secara aktif dan sukarela, baik karena alasan intrinsik maupun ektrinsik dalam keseluruhan proses kegiatan yang bersangkutan. Partisipasi masyarakat sebagai anggota organisasi dibagi dalam tiga macam kegiatan dalam proses pengembangan dan pembangunan yaitu partisipasi dalam pengambilan keputusan, partisipasi dalam pelaksanaan dan partisipasi dalam pengambilan manfaat. Partisipasi yang dilakukan oleh GOWA (Gucialit Orgasisasi Wisata Alam) dalam pengembangan agrowisata kebun teh Kertowono dilakukan dalam banyak kegiatan seperti melakukan rapat dengan masyarakat sekitar, promosi dan pelestarian lingkungan.

Menurut Desmita (2008: 198), partisipasi dalam pengambilan keputusan artinya bentuk perbuatan berpikir dan hasil dari suatu perbuatan . Partisipasi ini terutama berkaitan dengan penentuan alternatif dengan masyarakat yang berkaitan dengan gagasan atau ide yang menyangkut kepentingan bersama. Dalam partisipasi ini masyarakat menuntut untuk ikut menentukan arah dan orientasi pembangunan. Wujud dari partisipasi ini antara lain seperti kehadiran rapat, diskusi, sumbangan pemikiran, tanggapan atau penolakan terhadap program yang ditawarkan.

Partisipasi dalam pengambilan keputusan yang dilakukan oleh GOWA yaitu menghadiri rapat, diskusi , mengemukakan pendapat dan ide dalam rapat yang dihadiri oleh masyarakat, meminta saran kepada masyarakat dan kerjasama dengan masyarakat dalam mewujudkan idenya. Kegiatan yang berjalan saat ini juga merupakan hasil pengambilan keputusan bersama. Salah satu kegiatannya yaitu mengadakan karnaval sebagai salah satu cara untuk melestarikan kesenian masyarakat Gucialit juga sebagai ajang promosi wisata kebun teh Kertowono. Adanya karnaval juga menarik pengunjung untuk berkunjung ke wisata kebun teh Kertowono. Dalam pelaksanaan karnaval semua yang berkaitan dengan kegiatan yang berjalan dilakukan atas keputusan bersama. Partisipasi dalam pengambilan keputusan yang dilakukan GOWA adalah kegiatan karnaval tahunan, promosi dan konservasi hutan.

Menurut Kaselaran dkk (2015: 8), partisipasi dalam pelaksanaan merupakan keterlibatan masyarakat untuk ikut serta dalam mendukung terlaksananya pembangunan baik kontribusi dalam memberikan tenaga, bahan baku maupun finansial dengan memberikan sumbangan pembiayaan bagi terselengaranya pembangunan. Partisipasi dalam pelaksanaan merupakan kelanjutan dalam rencana yang telah digagas sebelumnya baik yang berkaitan dengan perencanaan, pelaksanaan maupun tujuan. Partisipasi dalam pelaksanaan meliputi menggerakkan sumber daya, kegiatan administrasi, koordinasi dan penjabaran program.

Partisipasi dalam pelaksanaan yang dilakukan GOWA dalam pengembangan agrowisata kebun teh Kertowono yaitu promosi lewat sosial media dan melakukan kegiatan konservasi hutan. Promosi lewat media sosial tidak hanya dilakukan GOWA saja tetapi juga masyarakat dan melibatkan PTPN XII dan Dinas Pariwisata. Konservasi hutan dilakukan GOWA dengan menyediakan pemandu wisata. Pemandu wisata dari GOWA yang disediakan dapat meminimalisir kegiatan negatif yang mungkin dilakukan oleh wisatawan, seperti mencorat-coret beberapa fasilitas, buang air disembarang tempat atau berniat mencari tempat untuk dapat melakukan tindak 
asusila dan lain-lain. Selain itu, pemadu wisata juga dapat digunakan sebagai polisi hutan yaitu meminimalisisr adanya perusakan hutan.

Menurut Sagitta (2016: 313), partisipasi dalam pengambilan manfaat yang merupakan bentuk keterlibatan masyarakat untuk turut menikmati dan memanfaatkan hasil-hasil pembangunan yang sudah terlaksana. Bukan hanya menikmati, tetapi masyarakat juga diharapkan dapat berpartisipasi dalam menjaga, merawat, dan memelihara hasil-hasil pembangunan yang telah dilakukan. Pemanfaatan hasil pembangunan tersebut diharapkan dapat mengungkit daya kreatifitas masyarakat, kegiatan ekonomi dan mobilitas sosial, peningkatan kesejahteraan masyarakat, yang pada akhirnya dapat mencapai pembangunan yang lebih baik lagi.

Partisipasi dalam pengambilan manfaat yang dilakukan GOWA yaitu memberikan manfaat ekonomi dan lingkungan kepada GOWA juga masyarakat. Masyarakat mendapatkan manfaat ekonomi, karena dilibatkan untuk menjadi pemandu wisata, penjaga parkir serta diberi kebebasan untuk berjualan di lokasi wisata kebun teh Kertowono. Pendapatan masyarakat meningkat dengan adanya wisata kebun teh Kertowono dengan bekerja sebagai pemandu, tukang parkir maupun berjualan di sekitar wisata. Selain memberikan manfaat ekonomi kepada masyarakat, GOWA juga memberikan manfaat lingkungan. Adanya pemandu wisata yang disediakan oleh GOWA juga membantu menjaga kelestarian lingkungan dengan melakukan patrol untuk menghindari adanya perusakan hutan.

\section{PENUTUP}

Berdasarkan hasil penelitian dan pembahasan, maka dapat diambil kesimpulan bahwa partisipasi GOWA dalam pengembangan agrowisata kebun teh Kertowono terdiri dari 3 bentuk partisipasi yaitu partisipasi dalam pengambilan keputusan, partisipasi dalam pelaksanaan dan partisipasi dalam pengambilan manfaat. Partisipasi dalam pengambilan keputusan GOWA dalam pengembangan agrowisata yaitu memberikan ide karnaval tahunan untuk melestarikan kesenian dan juga sebagai ajang promosi wisata kebun teh Kertowono serta menghadiri rapat dengan masyarakat sekitar Kecamatan Gucialit. Partisipasi dalam pelaksanaan yaitu melakukan promosi melalui sosial media dan melaksanakan konservasi lingkungan. Partisipasi GOWA dalam pemberiaan manfaat yaitu memberikan manfaat ekonomi dan lingkungan. Manfaat ekonomi yaitu masyarakat meningkat dengan adanya wisata kebun teh Kertowono dengan bekerja sebagai pemandu, tukang parkir maupun berjualan di sekitar wisata dan memberikan manfaat lingkungan yaitu adanya pemandu wisata yang disediakan oleh GOWA juga membantu menjaga kelestarian lingkungan dengan melakukan patrol untuk menghindari adanya perusakan hutan. Saran yang dapat diberikan terkait penelitian yaitu dukungan pemerintah daerah maupun setempat mendukung adanya pengembangan agrowisata kebun teh Kertowono dengan memperbaiki infrastruktur jalan menuju wisata yang kurang memadai, GOWA diharapkan mengembangkan objek-objek yang ada, memoles dan membuat beberapa fasilitas dan wahana untuk menambah daya tarik pengunjung dan mengingat lokasi agrowisata kebun teh Kertowono memiliki potensi yang memungkinkan terjadinya bencana alam, GOWA dan masyarakat perlu waspada dan siaga untuk mengurangi penyebab terjadinya bencana alam seperti banjir dan tanah longsor.

\section{DAFTAR PUSTAKA}

Desmita. 2008. Psikologi Perkembangan. Bandung: Remaja Rosdakarya.

Isbandi, Adi Rukminto. 2007. Perencanaan Partisipatoris Berbasis Aset Komunitas: Dari Pemikiran Menuju Penerapan. Depok: FISIP UI Press.

Kaselaran, Ferdinand dkk. 2015. Partisipasi Dalam Program Nasional Pemberdayaan Masyarakat Mandiri Perkotaan Kelurahan Taas Kota Manado. Acta Diurna: 4(5)

Mardikanto, T. 2013. Pemberdayaan Masyarakat Dalam Perspektif Kebijakan Publik. Bandung: Alfabeta.

Sagita, Novie Indrawati. 2016. Partisipasi Warga Masyarakat Dalam Penilaian Kinerja Kecamatan Di Kota Bandung. Jurnal Ilmu Pemerintahan: 2(2)

Winardi, 2000. Azas-azas Management. Bandung: Mandar Maju 